\title{
The Anglosphere beyond Security
}

Srdjan Vucetic, University of Ottawa

August 2018 (6600 words)

\section{Introduction}

Contemporary Anglospherism - a convenient shorthand for recent calls for more cooperation and unity between select English-speaking polities - draws considerable potency from the existence of the networks that make up the already existing 'Anglosphere in security.' The argument I wish to make in this chapter is twofold: first, the historical relationship between these two Anglospheres is one of mutual constitution - one in which security defines political visions and vice versa. Second, this relationship has a racialised history that is crucial for an informed understanding of not just the Anglosphere but of international order itself. ${ }^{1}$

I begin by considering the recent rise of the Anglosphere discourse, with special reference to 'Brexit.' Next, I outline the broad contours of the interlocking, mutually supportive networks that constitute the Anglosphere in security. I then turn to a discussion of the hegemonic transition from Britain to America and the critical role played by Winston Churchill in the genesis of the AngloAmerican (now called UK-US) special relationship. In doing so, I situate the rise of the Anglosphere not in the context of the mortal Axis threat and the brooding power of the Soviet Empire, as in the conventional view, but in the context of the Victorian-era operations to promote unity and superiority of 'the Anglo-Saxon race' or, as Churchill would later put it, 'the Englishspeaking peoples.' My conclusion is that we cannot grasp any aspect of the Anglosphere phenomenon today without due attention to the imperial drive towards the conquest, exploitation and domination of 'inferior' peoples.

\footnotetext{
${ }^{1}$ The latter builds on Srdjan Vucetic, The Anglosphere: A Genealogy of a Racialized Identity in International Relations (Palo Alto, Stanford University Press, 2011). And earlier version of this chapter was also presented at $\mathrm{UZH}$, Zurich in September 2017. For written comments, the author is grateful to Ben Wellings and an anonymous reviewer. Usual disclaimers apply.
} 


\section{The Anglosphere, Anglospherism and Brexit}

The word 'Anglosphere' entered the Shorter Oxford English Dictionary in 2007, having first appeared in Neal Stephenson's 1995 science fiction novel Diamond Age. There are several explanations of how this happened. Mine begins with George Orwell's Nineteen Eighty-four (1949). There, the Anglosphere is 'Oceania,' a totalitarian polity created by the 'absorption' of the British Empire by the US. The similarities between Orwell's and Stephenson's novels are unmistakable: both authors imagine a future political-economic world as a three-way contest among culturally defined entities. But the differences are important, too. While Orwell depicts a dog-eat-dog fight for survival between three slave-owning 'superstates'- Oceania versus Eurasia versus Eastasia - Stephenson dreams up an open and peaceful competition for markets and nanotechnologies among pluralistic yet decidedly civilizational entities he calls 'phyles'. The biggest three phylesare the Celestial Kingdom (Han Chinese), the Nippon (Japanese) and the Anglosphere, a.k.a. the 'Neo-Victorian' or 'Atlantan' phyle.

American entrepreneur and thinker James C. Bennett and American-British historian and poet Robert Conquest, the two individuals most responsible for turning the Anglosphere into a commonplace concept for political conservatives and making the word itself an entry in the Oxford English Dictionary, can be safely described as science fiction fans. In September 1999, Conquest gave a speech to the New York-based English-Speaking Union about the need for an 'AngloOceanic community' - a global community of English-speaking peoples who shared common cultural and sociopolitical values. ${ }^{2}$ Four months later at the Hudson Institute conference in Washington, Bennett made a broadly similar argument, albeit for a 'network commonwealth' he called 'the Anglosphere'. 3

\footnotetext{
2 For a version of this speech, see Robert Conquest, 'Towards an English-speaking union', The National Interest 57, 419 (1999), 64-70.

${ }^{3}$ His speech was based on a 1997 essay, parts of which Bennett published in op-ed and essay forms (National Post, January 2000; Orbis 2002). Bennett knew Stephenson, and Conquest later adopted the term Anglosphere from Bennett. The author's conversations and correspondence with Bennett, from 2009 to 2017. For Bennett's conceptualisation of networks, see his The Anglosphere Challenge: Why the English-speaking Nations Will Lead the Way in the Twenty-First Century (Lanham: Rowman and Littlefield, 2004) and compare with Alan Lester, Imperial Networks: Creating Identities in Nineteenth Century South Africa and Britain (London: Routledge, 2001).
} 
Just as Orwell's Oceania mirrored the 1940s, Stephenson's Anglosphere mirrored the 1990s. However, the events of 9/11 and subsequent US-led war on terror grafted new meanings onto the term, with post-Cold War liberal triumphalism giving more space to Huntingtonian 'clash of civilizations' anxieties. It is in the latter context that the Anglosphere became a political term. Margaret Thatcher, who heard Bennett speak at Hudson, became an earlier adopter, while George W. Bush, Tony Blair, Manmohan Singh, Gordon Brown, John Howard, Tony Abbott and Stephen Harper merely flirted with it. ${ }^{4}$ By the 2010s, the Anglosphere began to enter government publications. Consider the House of Commons Library research paper 'Leaving the EU' from 1 July 2013. ${ }^{5}$ Opening with a reading of Prime Minister David Cameron's Bloomberg Speech, the paper delves into a discussion, over 100 pages long, of Brexit's — not the word used by the paper's anonymous authors - frequently asked questions. In it, the Anglosphere makes two key appearances. In Section 4, entitled 'Alternatives to EU membership', the Anglosphere, in quotations marks, is ranked last, below the European Free Trade Area, the European Economic Area and 'the Swiss model'. Section 5, 'Foreign and defence policies', notes that the Anglosphere 'has been mentioned from time to time in Parliament', including indirectly by William Hague, foreign secretary in the Cameron government, who in 2010 'echoed some of the themes and language used by "Anglospherists", 6

'Leaving the EU' untangles what the Anglosphere means primarily through extensive quotations from three conservative Anglospherists - the aforementioned Bennett and Conquest plus British historian Andrew Roberts. The paper casts a sceptical eye. Anglospheric ideas, Section 4 explains, have a long history of failures, starting with the now forgotten 1911 Imperial Conference called for 'common foreign and defence policies for the whole Empire'. Section 5 hits even harder. The renaissance of Anglospherism is now over, thanks to the combination of Iraq and Afghanistan, where the 'limits of US power' were laid bare, and the Great Recession, which for many

\footnotetext{
${ }^{4}$ For the role of media tycoons Conrad Black and Rupert Murdoch, pundits Christopher Hitchens and Andrew Sullivan and other factors influencing the rise of the Anglosphere idea, see Srdjan Vucetic, 'Anglobal Governance?' Cambridge Review of International Affairs 23: 3 (2010), 455-474; Ben Wellings and Helen Baxendale, 'Euroscepticism and the Anglosphere: traditions and dilemmas in contemporary English nationalism' Journal of Common Market Studies 52: 1 (2015), 123-39; and Michael Kenny and Nick Pearce, Shadows of Empire: The Anglosphere in British Politics (Cambridge: Polity, 2018), Chs. 6-7.

${ }^{5}$ House of Common Library, 'Leaving the EU,' Research Paper 13/42 (2013). Not to be confused with Thomas Brown and Eren Waitzman, 'Leaving the European Union: Future UK-EU Relationship', House of Lords Library briefing of November 25, 2016.

${ }^{6}$ House of Common Library, 'Leaving the EU', p. 84.
} 
completely stripped so-called Anglo-Saxon capitalism of its authority. ${ }^{7}$ The critique is then expanded through the voices of conservative political commentators from the US, the UK and Australia who have identified several problems with the Anglosphere argument. These included ignorance of demographic projections from the US Census Bureau or of the fact that Washington was increasingly interested in the Asia-Pacific, not the Atlantic.

Parliamentary library research papers are of course a political genre on their own. Produced to be used by parliamentarians, parliamentary committees and parliamentary associations at multiple stages of the legislative process, such publications come in many forms, but they all make similar claims to brevity, non-partisanship, reliability, multi- and inter-disciplinarity and timeliness. The House of Commons Library paper fits the description in the sense that it treated the Anglospheretalk as legitimate and worthwhile of critical attention. This was astute. In the run-up to the 2016 referendum, more than a few leading 'Brexiteers', including David Davis, Liam Fox, David Willetts, Michael Gove, Daniel Hannan, Michael Howard, and Boris Johnson, entertained the 'Anglosphere option'. ${ }^{8}$ Following the referendum, as various Brexit deadlines drew near, the stock of the idea rose steeply in the same circles, informing or spurring new visions on the future of Britain's engagement with the world - from Theresa May's 'Global Britain' to the even more nebulous 'CANZUK.',

The rise to US presidency of Donald Trump is the other major shift in the Euro-Atlantic political landscape of 2016. Its impact on Anglosphere possibilities is harder to discern. In his first interview with the British press as president-elect, Trump asserted that the UK has a 'special place' in his heart and pledged to support a post-Brexit UK-US trade deal. From one point of view, subsequent actions on both sides of the Atlantic-May's rush to be the first foreign leader to meet with Trump on Day 7 of his presidency, for example - are indicative that such a deal may be possible in the future, which, in turn, would probably solidify both the Anglosphere in security and Anglosphere advocacy. Viewed from another perspective, however, Trump's presidency has been so radical and chaotic that it is equally possible that Washington will end up turning its back on all US foreign

\footnotetext{
${ }^{7}$ House of Common Library, 'Leaving the EU', p. 83.

8 Duncan Bell, 'The Anglosphere: new enthusiasm for an old dream,' Prospect, January 19, 2017, and Yves Eudes, 'L'anglosphère, la planète des " brexiters heureux "', Le Monde, March 28, 2017.

${ }^{9}$ Duncan Bell and Srdjan Vucetic, 'Backward, March! Brexit, CANZUK, and the Legacy of Empire', Paper presented at the 59th Annual Convention of the International Studies Association in San Francisco, California, April 4-7, 2018.
} 
policy nostrums - from the so-called special relationship to the so-called liberal international order. In Sir Michael Howard put it, days after the Trump election: "Ah, "the special relationship.” It was a necessary myth, a bit like Christianity. But now where do we go?'10

\section{The Anglosphere in Security}

The authors of the 2013 House of Commons Library researchers did not think of the Anglosphere as a viable economic and much less political alternative for Britain. Yet, their own paper points to an already existing Anglosphere in the domain of 'security'. Indeed, Section 5.16, 'Relations with the United States', is mostly about the UK-US special relationship as well as the reasons why the US ‘values', and 'relies on', British contributions to European defence. ${ }^{11}$

The basic contours of this arrangement are well known, starting with its awesome nuclear and intelligence foundations. ${ }^{12}$ Space allows me to consider only the latter: formalised through a series of 'UKUSA' agreements between 1940 and 1948, the 'special intelligence relationship' emerged not as a bilateral relationship so much as a network connecting American assets with those from across the 'British world system.' ${ }^{13}$ What better way for Washington to keep an eye on its enemies, first the Axis and then the Soviets, than with the help of Britain's ocean-spanning Empire, especially all those bases "in the Mediterranean and in vast expanses east of Suez"? ${ }^{14}$ A US State Department paper from 19 April 1950 puts it thus:

\footnotetext{
${ }^{10}$ Quoted in Ian Buruma, "The End of the Anglo-American Order," The New York Times, November 29, 2016.

11 'Leaving the EU', p. 81.

12 The literature on the subject is vast and growing. For a recent overview, see David Hastings Dunn and Edward Avenell, 'US-UK Special Relationship' in Patrick James et al (eds) Oxford Bibliographies in International Relations. Oxford University Press. DOI: 10.1093/obo/9780199743292-0189.

${ }^{13}$ For the phrases in the inverted commas, see, respectively, Rhodri Jeffreys-Jones, In Spies We Trust: The Story of Western Intelligence. (Oxford: Oxford University Press, 2013), and John Darwin, The Empire Project: The Rise and Fall of the British World-System, 1830-1970 (Cambridge: Cambridge University Press, 2009).

${ }^{14}$ R.K Webb, Modern England: From the 18th century to the present (London: George Allen \& Unwin), $1980, \mathrm{pp}$. 584-5.
} 
The British and with them the rest of the Commonwealth, particularly the older dominions, are our most reliable and useful allies, with whom a special relationship should exist. This relationship is not an end in itself but must be used as an instrument of achieving common objectives. ${ }^{15}$

Reading this backwards, we of course see the so-called Five Eyes. Although Canada formally joined the UKUSA intelligence pact in 1948, with Australia and New Zealand following suit in 1956, all three countries had participated in the pact from the start: 'While the Dominions are not parties to this agreement, they will not be regarded as third parties'. ${ }^{16}$

The Five Eyes constitutes the core of what I call the Anglosphere in security. Prior the Snowden disclosures - the release in 2013 of cache of leaked documents by Edward Snowden, a former contractor with the National Security Agency and an alleged Russian spy-only the most savvy world politics-watchers were aware that Australia, Canada, New Zealand, the UK and the US were members of the most exclusive intelligence pooling club in the world. But when Five Eyes senior officials met in April 2017 at a luxury resort in Arrowtown, in New Zealand's Otago region, the media was ready to grill Prime Minister Bill English and his spokesperson about it and to snap photos of FBI director James Comey disembarking the plane at Queenstown Airport. As one widely syndicated Reuters explainer put it, the Arrowtown meeting focused on everything from North Korea and cyber security to 'more mundane topics like managing diversity in the workplace and how to prevent whistleblowers. ${ }^{17}$

The Five Eyes includes up to twenty different intelligence agencies, the 'lead agencies' being the NSA in the US, Government Communications Headquarters (GCHQ) in the UK, the Communications Security Establishment in Canada, the Defence Signals Directorate in Australia and the Government Communications Security Bureau in New Zealand. ${ }^{18}$ What is still mostly

\footnotetext{
${ }^{15}$ FRUS 1950, III p. 879-90, as cited in John Baylis, Anglo-American Relations Since 1939. The Enduring Alliance. (Manchester: Manchester University Press), 1997, p.61.

${ }^{16}$ Article $6 a$ of the 1946 UKUSA treaty. Bill Robinson, 'The Communications Security Establishment: What do we know? What do we need to know?', Talk at the University of Ottawa, November 23, 2016. For further details, such as why and how Washington reserved the right to deal directly with Canada and with the other dominions through London, see Richard J. Aldrich, The Hidden Hand: Britain, America and Cold War Secret Intelligence (London, John Murray, 2001) and Jeffrey T. Richelson and Desmond Ball, The Ties That Bind: Intelligence Cooperation Between the UKUSA Countries (Boston: Unwin Hyman, 1990).

${ }^{17}$ 'Intelligence officials from "Five Eyes" gather in New Zealand: sources', The Globe and Mail, Apr. $24,2017$.

${ }^{18}$ For further context, see Zygmunt Bauman et al 'After Snowden: Rethinking the impact of surveillance', International Political Sociology 8.2 (2014): 121-144.
} 
unknown is that this 'network' is but one of the decades-old networks that bring together hundreds if not thousands of 'security assets' on a regular basis. Indeed, mere months before the aforementioned Arrowtown meeting, New Zealand hosted Exercise Dark Raven, a ten-day event at the Burnham Military Camp in Christchurch whose main purpose was to test the readiness and interoperability of 'ABCANZ' coalition partners - the American, Australian, British, Canadian and New Zealand armies - in defence intelligence. Such exercises are not secret, yet information about them can be found only in government press releases and military magazines. ${ }^{19}$ What is more, this is not a function of the size of such gatherings; for example, none of the top Canadian dailies reported on Maple Resolve, a military exercise that in May 2017 saw 7,000 soldiers from the same pentagonal coalition descend on Wainwright, Alberta.

As the 'old' dominions further de-dominionised ('gained independence') after World War II, they also formalised their alliances with the US. ABCA cooperation, for example, was institutionalised via a 1947 'standardisation plan' for the American, British, and Canadian Armies - the 'ABC Armies'. In 1963, the Australian Army joined, adding the second 'A' to the group's name. The New Zealand Army, an observer since 1964, became a full-fledged member in 2006, hence the more recent interchangeability of the acronyms ABCA and ABCANZ. In fact several ABCANZlike networks eventually came into existence: AUSCANNZUKUS, which covers sea operations for the five countries, the Combined Communications Electronics Board, Air and Space Interoperability Council, the Technical Cooperation Program, and the Combined Space Operations Initiative.

Other such networks are yet to be named or identified publicly. A good example is ABCANZ special force operational and institutional cooperation. This, too, was once seen as purely pragmatic. In 1952, Frank Wisner, the CIA operative in charge of covert operations, (in)famously confided to Kim Philby that 'whenever we want to subvert any place, we find the British own an island within an easy reach. ${ }^{20}$ Today, however, covert action cooperation is arguably an indelible

\footnotetext{
19 'Soldiers From Four Nations Receive Powhiri Welcome In New Zealand', Esprit de Corps, October 28, 2016. Government of Canada News Release, 'Intelligence Soldiers Work Together in Exercise DARK RAVEN', September 5, 2016 http://news.gc.ca/web/article-en.do?nid=1120389 Such developments have all but eluded alliance scholars. See Patricia Weitsman, Waging War: Alliances, Coalitions, and Institutions of Interstate Violence (Palo Alto, CA: Stanford University Press, 2014), pp. 38-9.

${ }^{20}$ Rhodri Jeffreys-Jones, In Spies We Trust, p. 96.
} 
aspect of Five Eyes activity, at least as far as GCHQ and the CIA are concerned. ${ }^{21}$ Also worthy of consideration is a rather unique network of defence trade cooperation treaties that tie the Five Eyes countries together via removal of a number of restrictions on military goods transfers. ${ }^{22}$

Looking statistically at US-led military interventions since Korea, it is prima facie true that Anglosphere forces 'fight shoulder to shoulder'. ${ }^{23}$ A similar pattern exists at the level of day-today operational and tactical cooperation. Canada's policy on the Iraq War in 2003 is an example: the Chrétien government's decision to stay out was mostly a public relations stunt given that Canada supported the war effort, partly by keeping dozens of Canadian armed forces members embedded in the US and UK invasion forces. ${ }^{24}$ This behaviour is to be expected from the perspective of path dependence: governments keep practicing what they have practiced before because continuity usually carries more benefits than change and sometimes also because change is literally unthinkable. ${ }^{25}$

Another good indicator of Anglosphere closeness is the relative ease by which military professionals and citizens of one ABCANZ member country can join the armed forces of another. In 2012, the Royal Canadian Air Force took advantage of the UK government's cuts to its armed forces to recruit six British fighter jet pilots. Defence diplomacy institutions point in the same direction. One example is the Canadian Forces' program 'Soldier On', a joint initiative between the Department of National Defence and the Canadian Paralympic Committee, that has since 2006

\footnotetext{
${ }^{21}$ Rory Cormac, Disrupt and Deny: Spies, Special Forces, and the Secret Pursuit of British Foreign Policy (Oxford: Oxford University Press), p. 79, 265, 276. The Chagos Islands are a particularly striking case study of the broader politics of this activity. See Peter Harris, 'Decolonising the Special Relationship: Diego Garcia, the Chagossians, and Anglo-American Relations.' Review of International Studies 39: 4 (2013), 707-727; and Mark B. Salter, and Can E. Mutlu, 'Securitisation and Diego Garcia', Review of International Studies 39:4 (2013), pp. 815834.

${ }^{22}$ As of 2013, the US has them with Australia, the UK, and of course Canada. 'Defense Trade Cooperation Treaties \& Resources', Retrieved on 12 April 2015 from http://www.pmddtc.state.gov/treaties/. The Anglosphere in security arguably obtains in military transfers patterns, too: Srdjan Vucetic and Atsushi Tago, "Why Buy American? The International Politics of Fighter Jet Transfers", Canadian Journal of Political Science 48: 1 (2015), 101-124. ${ }^{23}$ Srdjan Vucetic 'Bound to Follow? The Anglosphere and US-led Coalitions of the Willing, 1950-2001', European Journal of International Relations 17: 1 (2011), pp. 27-49.

${ }^{24}$ Ottawa also maintained a significant contingent of air and naval forces in the theatre of operations in addition to committing ample military resources to the US-led war in Afghanistan. For a pre-Wikileaks analysis of this policy episode, see Srdjan Vucetic, 'Why Did Canada Sit Out the Iraq War? One Constructivist Analysis', Canadian Foreign Policy 13: 1 (2006), pp. 133-53. On the relative irrelevance of high-office public political disagreements in day-today intelligence cooperation, also see Jeffreys-Jones, In Spies We Trust, p. 140.

${ }^{25}$ Vucetic, The Anglosphere, p.153-4.
} 
brought together injured soldiers from the ABCANZ militaries to Whistler, British Columbia, for wintertime physical and recreational activities.

Much better known is the Invictus Games, a spectacular Paralympic-style event for wounded, injured or sick armed services personnel and veterans. Although not exclusive to participants from ABCANZ countries, the Invictus Games are very much centered on them, considering their celebrity sponsorships and endorsements (the UK's Prince Harry, Canada's Justin Trudeau), commemorations (World War II, Afghanistan) and the locations in which they took place (London, Orlando, Toronto, Sydney). ${ }^{26}$ All of these cooperation and commemoration practices have an affective dimension. Indeed, the phrase 'fighting shoulder to shoulder' can be said to refer not so much to the actual company of others during conflicts as to the endless multimodal replaying of images that produce shared emotional experiences, which, in turn, profoundly shape the perceptions, motivations and intentions of political actors. ${ }^{27}$

The Anglosphere in security is slowly receiving recognition in major government documentslook no further than the latest white papers on defence in Australia, Canada and New Zealand, all of which mention the Five Eyes alliance and its beneficial impact for information-gathering, costsaving and burden-sharing. More important, this Anglosphere is increasing in scope and depth. When senior border and immigration bureaucrats met in February 2015 in Washington to discuss biometric data sharing under the aegis of the Five Country Conference, they were addressing 'security' much like the aforementioned spies and soldiers who respectively in convened in Arrowtown and Christchurch. Tim Legrand's analysis of 23 Anglosphere policy networks - this number should be treated as a sample - shows that such discussions are now not only ubiquitous and regular across most 'new security domains', but that they also yield direct policy transfers and, in some cases, provide actual governance functions. ${ }^{28}$

Viewed from the perspective of International Relations (IR) theory, the Anglosphere no doubt counts as a mature 'security community' — an integrated, interdependent zone within which large-

\footnotetext{
${ }^{26}$ Retrieved on 6 May 2017 from https://invictusgamesfoundation.org/games/toronto-2017/

27 See, respectively, Sam Edwards, Allies in Memory: World War II and the Politics of American Commemoration in Europe c. 1941-2001 (Cambridge: Cambridge University Press, 2015) and Marcus Holmes, Face-to-Face Diplomacy: Social Neuroscience and International Relations (Cambridge: Cambridge University Press, 2018).

${ }^{28}$ Tim Legrand, 'Elite, exclusive and elusive: transgovernmental policy networks and iterative policy transfer in the Anglosphere', Policy Studies 37:5 (2016), 440-455.
} 
scale use of violence is 'unthinkable'. ${ }^{29}$ Canada and the US indeed formally acknowledged this fact already in the 1930s, when their governments stopped updating war plans against each other. This community is variously characterised by common values, shared 'emotional beliefs', mutual sympathy and trust, and collective or at least overlapping identity. ${ }^{30}$ Indeed, what Henry Kissinger said about the 'Special Relationship' in 1982 easily applies to the Anglosphere in security more broadly:

The wartime habit of intimate, informal collaboration thus became a permanent practice, obviously because it was valuable to both sides. The ease and informality of the Anglo-American partnership has been a source of wonder - and no little resentment - to third countries. Our postwar diplomatic history is littered with Anglo-American 'arrangements' and 'understandings', sometimes on crucial issues, never put into formal documents. ${ }^{31}$

To be sure, neither habitual intimacy nor seamless informality nor 'third country resentment' negate the existence of intramural clashes, power asymmetries, and a manifest lack of 'specialness' in some areas, most of all in bilateral economic relations. ${ }^{32}$ Yet even the arch-realist Kissinger admitted that the understandings outnumbered the misunderstanding and that the latter tended to be short-lived and repairable - recall, for example, the Anglo-American military ('peacekeeping') intervention in Jordan and Lebanon in July 1958, mere two years after the Suez fiasco. ${ }^{33}$ In short, the balance of evidence suggests that there is nothing outlandish about the Anglosphere in security - it is a living, growing entity made up of multiple, overlapping and interlocking networks

\footnotetext{
${ }^{29}$ Karl Deutsch et al, Political Community at the International Level. New York: Doubleday, 1970 [1957], p. 5. Cf. Jennifer Mitzen, 'Security Communities and the Unthinkabilities of War', Annual Review of Political Science 19 (2016), 229-248.

${ }^{30}$ David Haglund, 'Is There a 'Strategic Culture' of the Special Relationship? Contingency, Identity, and the Transformation of Anglo-American Relations', in Contemporary Anglo-American Relations: A 'Special Relationship'? ed. Alan Dobson and Steve Marsh (London: Routledge, 2013), pp. 26-51.

${ }^{31}$ Henry Kissinger, 'Reflections on a Partnership: British and American Attitudes to Postwar Foreign Policy', May 10, 1982 speech to the Royal Institute of International Affairs, in commemoration of the Bicentenary of the Office of the Foreign Secretary. Available http://www.larouchepub.com/other/2002/2901 kissinger.html. Also see Kissinger, The White House Years (New York: Little Brown and Co., 1979), p. 90.

${ }^{32}$ For balanced overviews, see Kathleen Burk, Old World, New World: Great Britain and America from the Beginning (New York: Atlantic Monthly Press, 2008); and Adam Tooze, The Deluge: The Great War, America, and the Remaking of the Global Order, 1916-1931 (London: Allen Lane, 2014). For further context, see Marc-William Palen, 'Empire by Imitation? US Economic Imperialism within a British World System', in Martin Thomas and Andrew Thompson, eds., The Oxford Handbook of the Ends of Empire (Oxford: Oxford University Press, 2018). ${ }^{33}$ On the counterfactual validity of community norms, see Vucetic, The Anglosphere, p. 149.
} 
and communities of practice whose scope, depth and durability we are only beginning to fully appreciate.

\section{Victorian Virtualities}

The rise of the Anglosphere in security began with the peaceful transition from British to American hegemony. Many IR theorists think that all hegemonic transitions are war-prone; some think that all of them resulted in war-at least, some of them would add, before the advent of nuclear weapons. ${ }^{34}$ The Anglo-American case stands as an exception. In the decades following the American War(s) of Independence, Anglo-American relations mostly oscillated between rivalry and outright enmity. Once all outstanding issues from the American Civil War were settled in the 1870s, however, London and Washington found fewer and fewer reasons to go to war-and more and more reasons to cooperate, both covertly and overtly. The 'great rapprochement' ushered in the great shift. By the time Churchill sat down to write his History of the English-Speaking Peoples, the transition from Pax Britannica to Pax Americana was well under way or more likely already over. $^{35}$

Realist IR scholars tend to explain this puzzle with reference to British appeasement-cold calculus on Britain's national interests that implied the necessity of peaceful relations with the transatlantic upstart. ${ }^{36}$ From the war scares over Venezuela in 1894-95 and again in 1902-03 to the Washington Naval Conference in 1921 to the Suez Crisis in 1956, the British leadership consistently gave in to American demands, hence the relatively bloodless transition. Other IR scholars accentuate other developments. For liberals, the primary development is shared

\footnotetext{
${ }^{34}$ See Graham Alison et al, Thucydides Trap Case File: Sixteen Cases of Rise vs. Rule. Belfer Center 2013, http://belfercenter.ksg.harvard.edu/publication/24928/thucydides trap case file.html Also see Andrew Gamble, 'Hegemony and Decline: Britain and the United States', In Patrick Karl O'Brien and Armand Clesse, eds. Two Hegemonies: Britain 1846-1914 and the United States 1941-2001. Aldershot: Ashgate Publishing, 2002, pp. 127140; and Kori Schake, Safe Passage: The Transition from British to American Hegemony (New York: Harvard University Press, 2017).

${ }^{35}$ On the tensions that characterised this transition, see Schake, Safe Passage, Chs 9-10; Tooze, The Deluge, Chs 20-21; David Dimbleby and David Reynolds, An Ocean Apart: the Relationship between Britain and America in the Twentieth Century (London: BBC Books, 1988), Ch. 2; and Stephen Bowman, The Pilgrims Society and Public Diplomacy, 1895-1945 (Edinburgh: Edinburgh University Press, 2018), Ch.5.

${ }^{36}$ Lionel M. Gelber, The Rise of Anglo-American Friendship: A Study in World Politics, 1898-1906 (New York: Oxford University Press, 1938).
} 
democracy, while for Marxists it is the role of transatlantic capital class. There is some truth in all of these perspectives. However, what most puzzle-solvers overlook is the crucial role played by Anglo-Saxonism - a shared discourse of identity that positioned the two ruling establishments as not only 'kinsmen' but also the 'vanguard of civilisation'. Absent this deep racialised affinity, one of those two Venezuela crises might have well led to a colonial war and possibly a hegemonic one. The same goes for the case of mutual 'benevolent neutrality' during the Spanish and South African wars. Had they not thought of themselves as the leaders of the two branches of the Anglo-Saxon race, one that was in a state of competition with other races, the British and American leaders would have probably not acted as each other's sole cheerleaders in these conflicts. ${ }^{37}$

This period signals a break point after which Anglo-American relations moved along a different path from the one on which they had trodden. In contributing to the rise of Anglo-American cordiality at the turn of the twentieth century, Anglo-Saxonism also helped British leaders come to terms with the subsequent consolidation and extension of the global power of the US. It also helped American leaders interpret British followership as a function of reciprocated expectations of preferential treatment - what Churchill on March 5, 1946 in Fulton, Missouri referred to as the 'special relationship between the British Commonwealth and Empire and the United States'. ${ }^{38}$ This famous address, dubbed 'The Sinews of Peace' by its author but forever remembered as the 'Iron Curtain' speech, is in fact an outstanding twentieth century example of the co-constitution of the Anglosphere in security and political Anglospherism.

On one level, the speech reflected Churchill's interest in maintaining the Anglo-American military alliance given the rapid collapse of the postwar 'Big Three' condominium:

Fraternal association requires not only the growing friendship and mutual understanding between our two vast but kindred systems of society, but the continuance of the intimate relationship between our military advisers, leading to common study of potential dangers, the similarity of weapons and manuals of instructions, and to the interchange of officers. ${ }^{39}$

\footnotetext{
${ }^{37}$ Vucetic, Anglosphere, Chapters 2 and 6. For an alternative interpretation, see Schake, Safe Passage.

38 This draws on Srdjan Vucetic, 'The Fulton Address as Racial Discourse', in Alan Dobson and Steve Marsh, eds., Churchill and the Anglo-American Special Relationship (London: Routledge, 2017), 96-115.

${ }^{39}$ The speech is available at the website of the International Churchill Society. Retrieved on 2 February 2017 from https://winstonchurchill.org/resources/speeches/1946-1963-elder-statesman/the-sinews-of-peace/
} 
None of this was fantasy. The 'fraternity of the uniform' was strong in those years, and not just between the two navies. ${ }^{40}$ In intelligence, as mentioned earlier, the two nations had already committed themselves to 'peacetime' collaboration. Nuclear collaboration looked equally promising, too, in light of the Quebec (1943) and Hyde Park (1944) memoranda and the fact that Truman had not yet signed the McMahon Act (which, in August 1946, would end the practice of sharing of US nuclear know-hows and know-whys with Canada and the UK). There was also the Canada-US Permanent Defense Agreement, which Churchill duly mentioned in the speech. ${ }^{41}$

Yet, the Fulton address is also a timeless statement of Anglosphere advocacy. Its logic goes like this: if the threat of tyranny is a constant and if international governance mechanisms are by default too weak, then it is the world's best interest to support the Anglo-American alliance or, more accurately, 'Anglobal' governance. Rather than the 'iron curtain', the intended punchline of the speech, or, as the speaker himself put, its 'crux', was always the 'fraternal association of the English-speaking people'. It was in this context that Churchill in his speech predicted the special relationship giving birth to common citizenship between the two nations: 'Eventually there may come - I feel eventually there will come - the principle of common citizenship'.

A sceptic would say that the phrases 'special relationship' and 'fraternal association' were sufficiently new and devoid of content to allow different contemporary audiences to inscribe onto them different meanings. Indeed they did. One camp saw it as realistic and gutsy, one as hawkish, even inflammatory. But the latter camp was itself deeply divided. Many white liberals saw the former prime minister not as the saviour of Western civilisation but as a reactionary imperialist bent on playing the 'great game' with the Soviets. They also pinned their hopes on the newborn United Nations Organisation rather than the Combined Chiefs of Staff, the supreme military command for the Anglo-Americans forces established at the 1941 Arcadia Conference that in fact continued to operate right through the 1948 Berlin Blockade. Churchill's African American critics hit much harder. For them, the special relationship was nothing but the latest schema for

\footnotetext{
40 The phrase is from Joel J. Sokolsky, The Fraternity of the Blue Uniform: Admiral Richard G. Colbert, US Navy, and Allied Naval Cooperation (Newport, RI: Naval War College Press, 1991).

${ }^{41}$ Suffice it to say, Churchill could not possibly offer these terms to, for example, the French. See David Haglund, "The Case of the Missing Democratic Alliance: France, the 'Anglo-Saxons' and NATO's Deep Origins", Contemporary Security Policy 25:2 (2004): 225-51; Emile Chabal, 'The rise of the Anglo-Saxon: French perceptions of the AngloAmerican world in the long twentieth century', French Politics, Culture and Society 31: 1 (2013), 24-36; R.T. Howard, Power and Glory: France's Secret Wars with Britain and America, 1945-2016 (London: Biteback, 2016).
} 
maintaining what W.E.B. Du Bois called the 'colour line' - that is, for quashing the freedom of black and brown people on a global scale. The actor and activist Paul Robeson, arguably the world's most famous African American at the time, called it 'a more highly developed kind of benevolent Anglo-American imperialism'. ${ }^{42}$

African Americans who denounced the Fulton address were right about Churchill's racial supremacism. Although he never gave any speeches on the subject of race, his personal and political biographies are replete with acts of privileging white people, particularly fellow 'AngloSaxons'. These acts were historically commonplace and entirely in line with his early socialisation into the now forgotten world of 'Greater Britain'. As Duncan Bell has shown, Greater Britain is the Anglosphere's oldest conceptual predecessor. ${ }^{43}$ Developed in an eponymous bestseller published in 1868 by the British politician and author Charles Dilke, Greater Britain referred to a discrete global space governed from either London or Washington. Dilke's main argument, that this space needed a dramatic political re-organising, proved popular on both sides of the Atlantic. In the $1880 \mathrm{~s}$ and $1890 \mathrm{~s}$, scores of intellectuals and activists, including many well-known politicians, business leaders, journalists, and colonial administrators, weighted in with assorted plans and proposals for optimising Greater British power, which, for many of them, was synonymous with the power of 'the Anglo-Saxon race'. Churchill's parents partook in these conversations not just as consumers but as producers too-see the content of The Anglo-Saxon Review, the ‘quarterly miscellany' edited the by Churchill's American mother, Lady Randolph. ${ }^{44}$

Greater Britain was by no means a fantasy. With the rise of new ideological articulations, new forms of political participation, and new transportation and communication technologies, the late nineteenth century in fact saw a coming-together of an informal, loosely bounded, and de-centered cultural and economic community of English-speakers that James Belich calls the 'Anglo-

\footnotetext{
${ }^{42}$ Vucetic, 'The Fulton Address', p. 96. For more context, see Penny M. Von Eschen, Race Against Empire: Black Americans and Anticolonialism, 1937-1957 (Ithaca, NY: Cornell University Press, 1997), Clive Webb, 'Reluctant partners: African Americans and the origins of the special relationship', Journal of Transatlantic Studies 14: 4 (2016), 350-364; and Alexander Davis and Vineet Thakur, 'Walking the thin line: India's anti-racist diplomatic practice in South Africa, Canada, and ustralia, 1946-55,' International History Review 38: 5 (2016), 880-899. ${ }^{43}$ Duncan Bell, The Idea of Greater Britain: Empire and the Future of World Order, 1860-1900. Princeton: Princeton University Press, 2007.

${ }^{44}$ All ten volumes of this short lived publication (June 1899 to September 1901) are now available online through the University of Pennsylvania library: http://onlinebooks.library.upenn.edu/webbin/serial?id=anglosaxonrev.
} 
world'. ${ }^{45}$ The engine behind it was a historically unique and permanent large-scale transfer of population from the British Isles to both the US and the 'neo-Britains' - the 'settler revolution', to use the author's labels. ${ }^{46}$ Rather than their vicious brutality and unvarnished greed, Belich's focus is on the settler's remarkable ability to maintain close social, economic, cultural and political ties with the old country, hence his bold claim that late nineteenth century Greater Britain was nothing less than a 'virtual nation'. 47

Fin de siècle debates on the imperial political (de)centralisation generally focused on white AngloSaxons, while casting assorted colonial Others-Catholic Irish or Muslim Bengali elites, for example - in subordinate roles at best. The subsequent decline of this discourse did not actually spell the end of racial supremacism as such. ${ }^{48}$ By switching to the more neutral-sounding 'Englishspeaking peoples' in his writings and speeches, Churchill did not abandon his Victorian views so much as repackage them for mass consumption in the modern, 'post-colonial' era — a point emphatically made by Robeson, Du Bois and other African American critics of his speech. Indeed, when he mentioned common citizenship at Fulton, he was channeling a form of 'isopolitanism' that once aimed to make Greater British nationhood less virtual. ${ }^{49}$ And this was merely the first step, as the concluding sentence of the speech intimates: 'if all British moral and material forces and convictions are joined with your own in fraternal association, the high-roads of the future will be clear, not only for us but for all, not only for our time, but for a century to come.' 50

\section{Conclusion}

\footnotetext{
45 James Belich, Replenishing the Earth: The Settler Revolution and the Rise of the Anglo-world. Oxford: Oxford University Press, 2009.

${ }^{46}$ Research on the British diaspora - the British media like to describe it as 'the largest of any rich country' consistently shows that today half of all UK "ex-pats" live in Australia, New Zealand, Canada, and the US.

47 Belich, Replenishing the Earth: p. 209. Also see Darwin, The Empire Project, pp. 41-2.

${ }^{48}$ Sir Oswald Mosely's infamously re-appropriated the phrase in The Greater Britain, his 1932 manifesto for the newly established British Union of Fascists, and the last revival of the term was in mid-1960s, by a neo-Nazi political outfit called The Greater Britain Movement.

${ }^{49}$ Churchill also argued for common citizenship as prime minister, for example, at Harvard in 1943. For more context, see Duncan Bell, 'Before the democratic peace: Racial Utopianism, Empire and the Abolition of War', European Journal of International Relations 20: 3 (2014), 647-670.

${ }^{50}$ Belich at one points calls Greater Britain 'the really special relationship'. Belich, Replenishing the Earth, Ch. 16 (chapter title).
} 
Contemporary Anglospherism draws much of its inspiration from the existence of the Anglosphere in security - a convenient shorthand for the deep and durable networks of cooperation and collaboration between individual and institution actors situated in select English-speaking nations. My argument in this chapter has been that these two projects are in fact historically co-constituted, the central driver being the peaceful - and racialised - early twentieth century transition from British to American hegemony.

This chapter barely begins to engage with race as a critical and fundamental aspect of the Anglosphere. Going further 'beyond security' entails discussion of the ways in which 'likeminded' English-speaking polities informed each other's political, legal, social and economic development. This historical narrative would connect the colonial and post-colonial eras, that is, everything from the enslavement, dispossession, and near-extermination of various Others to the paternalist immigration policies and citizenship laws that shaped interactions with populations not part of the racialised Anglo communities to the selective support for decolonisation and development.

Our understanding of these connected histories has direct consequences for twenty first century Anglospherism. The historiography of the Anglosphere's constitutive elements has traditionally focused on the empire-builders rather than the subjects of empire-Churchill rather than his African American critics, for example. If we accept that racism manifests itself in knowledge production as well, this should not be surprising. But as more and more people reengage with the histories of those who in this historiography are excluded, minimised and silenced, as well as with coloniality as a present condition, it will become harder and harder to make a case for more cooperation and unity between select English-speaking nations. 